\title{
Managing Reputational Risk: A Reinsurer's View
}

\author{
Peter Forstmoser and Nikodemus Herger \\ Swiss Reinsurance Company, Mythenquai 50/60, Zurich CH-8022, Switzerland. \\ E-mail: Nikodemus_Herger@swissre.com
}

A company's reputation is a vital asset in building stakeholder trust; a resource that, given the risk of public scandal threatening every enterprise in today's information society, is nothing less than existential. No company can afford to abandon itself to the whims of public opinion; all must actively strive wherever possible to shape reputational opportunities and risks in their own best interest. Professional reputation management has quite simply become every company's duty. This article situates reputation management in the context of corporate values, corporate governance, corporate responsibility and the "triple bottom line"; in the context, that is, of the most fundamental elements of corporate policy. Indeed, only such a holistic approach can do justice to the complexity of the reputation phenomenon. In our reflections on the implementation of reputation management, we will be using Swiss Re as a concrete example, demonstrating in a detailed manner the relevant institutions, instruments and tasks. This implementation question involves a number of issues: corporate citizenship, sustainability management and corporate compliance, among others - but perhaps most importantly, the role reputation plays in a company's sustainable economic success.

The Geneva Papers (2006) 31, 409-424. doi:10.1057/palgrave.gpp.2510085

Keywords: reputation management; corporate responsibility; corporate governance; triple bottom line; sustainability management; public opinion

\section{Reputation: clarifying the concept}

Reputation is the product of communication. Ripperger's definition is based on this assumption. "Reputation," she writes, "[...] is public information regarding a player's trustworthiness. [...] A player's reputation reflects the information that third parties have on how trustworthy his behaviour has been in the past with regard to others." Thus, public opinion - and of course public communication as well - plays a key role in our understanding of reputation. What, then, are the characteristics of public opinion, which stands in such intimate connection with reputation?

Public opinion is built upon public information, that is, information accessible to everyone. ${ }^{2}$ In modern societies, the most elevated degree of access is enjoyed by the mass media and the online media. The issues served up by these media make up a large part of what people perceive as reality. Companies as well are publicly defined by and are exposed to - the reality that the public absorbs from the media. Surveys show

\footnotetext{
${ }^{1}$ Ripperger (1998, pp. 100, 183).

${ }^{2}$ Conditions for this free access are the freedoms of speech, of assembly and of the media. They are constitutionally guaranteed; see, for example, Swiss Federal Constitution, Articles 16, 17 and 22.
} 
that Swiss Re's stakeholders derive more than half of the information they can recall about the company from the mass media. ${ }^{3}$ This universal access implies an element of unpredictability. ${ }^{4}$ Unpredictable elements include natural catastrophes, terrorist attacks, questionable conduct - or even the selection and interpretation practices of the media itself. For many companies - and this definitely include reinsurers - this unpredictability entails both reputational and operational risks. ${ }^{5}$ The issues that excite public opinion can develop with maddening slowness or with dizzying speed - and in any direction. At any moment, a company might find itself embroiled in some new issue, and obliged to bind resources and know-how - if these are available - in an attempt to develop an appropriate response. The media have massively heightened the complexity of public issues, as well as accelerated their cycle. Thus, it has become entrepreneurial necessity to keep close tabs on public opinion through reputation management. Not to do so would be to expose the company to the media - who, as the dominant influence on public opinion, have considerable power to project almost any issue into the limelight at almost any time. ${ }^{6}$

Taken together, public opinion and reputation are a mirror allowing the corporation to see itself from the public perspective, based on the issues broached in public communication and by public opinion. For example, the media may mention Swiss Re in one form or another in connection with a broad range of issues, including financial performance, litigation, acquisitions, staff appointments and organizational restructuring, or as an "expert witness" in connection with natural catastrophes, terrorism, climate or mortality. Politicians, legal experts, scientists, journalists, investors, NGOs and many other players have equal access to the public dialogue, and observe Swiss Re's actions and decisions: they do this critically and according to their own criteria and values. ${ }^{7}$ This is typical in any pluralistic, democratic society: the participants - all participants - in the public communications scene render judgement according to their very own perspectives: according to yardsticks that may be moral, ethical, legal, cultural, social, environmental or economic in nature. Reputation is affected by literally every issue and every opinion - because anyone, at any time, can react publicly on any subject. The consequences of this conjunction of reputation and public opinion are clear: the decisions of a company's board and management produce ripples that spread far beyond the realm of business and into the social and environmental dimension: into culture, legislation and politics. ${ }^{8}$

\footnotetext{
${ }^{3}$ Swiss Re is a business-to-business enterprise. Such companies have contact with the broad public only indirectly, if at all, through the agency of business-to-consumer enterprises. This means that these business-to-business enterprises have considerable difficulty in generating broad public interest in their client issues, whereas the media closely observe and comment on their relations to investors, employees, NGOs and regulators.

${ }^{4}$ Luhmann (1996, p. 184).

${ }^{5}$ PricewaterhouseCoopers (np 2004, p. 14).

${ }^{6}$ Wiedmann and Buxel (2005).

${ }^{7}$ Luhmann (1991, pp. 77, 85ff).

${ }^{8}$ An example for the indirect effect of open communication, and for direct compliance and risk assessment on entrepreneurial activities is the decision by the Swiss bank UBS to retreat from its business relationships with Iran (Neue Zurcher Zeitung (2006)).
} 


\section{The triple-bottom-line approach}

As a response, corporate policy evolved over the course of the $1990 \mathrm{~s}^{9}$ and early $2000 \mathrm{~s}$ from its fundamental focus on profit maximization to a broader understanding: the triple-bottom-line approach. This can be seen in many ways: the stakeholder approach, the debate on sustainability, the corporate governance discussion and the corporate responsibility concept. If corporate governance provided the structural framework for implementing the triple-bottom-line approach, it was corporate responsibility that described a company's obligation to be sensitive to the needs of all of its stakeholders in its business operations - and this not as an outflow of philanthropy, but based on solid commercial interests.

As expression of Swiss Re's espousal of the concept of sustainable value, our mission statement includes the principle that "[W]e strive for balance between economic, social and environmental development in society at large". This company policy statement was also made as a reply to the developments in public communications mentioned above. The establishment of a triple-bottom-line approach is a response to the heightened scrutiny of companies in both business and non-business matters. The triple-bottom-line approach is based on the assumption that the value generated through entrepreneurial activity is not simply to be handed over to the owners (i.e., the shareholders) - but is to be bestowed in a sustainable manner agreed upon by all stakeholders: "The goal is to serve three masters at the same time, in a balanced manner: the shareholder through the maximisation of profit; the society through responsible corporate behaviour (social responsibility); and finally, the natural world around us by carefully husbanding the resources of nature and engaging in sustainable business practices (environmental responsibility)". ${ }^{10}$ Let us note, however, that Swiss Re is firmly anchored in the real world. This means that its goal - namely, to add value to the enterprise in a sustainable manner - remains fundamentally unchanged. This goal is a consequence of enlightened self-interest - not of altruism. It is based upon the conviction that sustainably enhancing a company's value is in the best interest of all stakeholders in the long run, and particularly of the shareholders - the constituency to which a listed stock corporation is ultimately responsible. ${ }^{11}$ Such a focus on creating long-term value is of considerable help in gaining a clear perspective with regard to certain notions and terms that are often used in a rather imprecise, not to say fuzzy, manner. We will be looking at three such terms below.

\section{Corporate social responsibility}

Aside from charity (to the measure defining good citizenship) and sponsoring (with the primary goal of enhancing its reputation), a corporation has only one single social responsibility: namely, to perform its own business activities in a professional and efficient way, and in compliance with its core values. In other words, in a corporation's

\footnotetext{
${ }^{9}$ Ulrich and Fluri (1995, pp. 85ff).

${ }^{10}$ Forstmoser (2005, p. 212).

${ }^{11}$ See Forstmoser (2003).
} 
daily life, the concepts "corporate responsibility" and "corporate citizenship" mean the successful attainment of business goals - and nothing else. This is in complete agreement with Milton Friedman's famous dictum that "the business of business is business".

Insurers and reinsurers, for example, have the task of actively managing risks, and thus of helping other industries embark on business activities that would be too risky if no risk transfer or risk mitigation were possible. To provide this protection - not pro bono, but as a business transaction intended to be profitable (for no business is sustainable without profits) - to provide this protection, we repeat, is corporate citizenship and is corporate responsibility in the insurance industry. This applies analogously to other industries. They too should offer services as they are supposed to: efficiently, profitably, cost effectively and to a high standard.

The "invisible hand" still works; the interests of corporations and of society can be aligned - provided they both take a long-term view. This is why sustainability is close to corporate social responsibility, and is (or should be) the common interest of corporations and society.

\section{Charity, donations, pro bono activities}

An enterprise can and should play an active role in the community in the measure that might be expected of any public-spirited individual. It goes without saying that nothing prohibits a corporation from being a good citizen. Indeed, it serves the corporation's own best interests to be an active, contributing citizen, because no one can expect a favourable environment for their own activities if they do not take care of this environment, and do not take an active part in shaping it.

A large corporation, for example, is able to afford, and should be expected to support their employees in pro bono activities; it can afford and should be expected to provide a certain number of workplaces for handicapped people; it can, and also should help the underprivileged; and it should support social activities.

It is just as obvious, however, that there are quite narrow limits to such altruistic activities in a public company, for the law and the market both require publicly owned corporations to be profitable. It would thus be suspect to make any charitable donation that would significantly impact company profits: it is the shareholders' right to decide on the disposition of a company's funds.

\section{Sponsoring}

Although sponsoring can be highly beneficial for the society, its goal is not altruistic. Sponsoring expenses are business expenses, and the corporation expects a payback in some form: perhaps an enhanced reputation - that is, brand - or expanded business opportunities.

Sponsoring is particularly useful for both sides - society and the corporation where the commitments are in areas closely related to the company's business. If Swiss Re sponsors conferences on global ageing or on the greenhouse gas problem; if it creates an award for sustainable watershed management; if it finances an international 
TV series on climate change: then, these activities are credible for a company that has a keen business interest in a predictable future and a sustainable environment. Through these activities, Swiss Re gains credibility as an organization that is aware of trends with a larger impact both on society and its own business. However, if Swiss Re were to invest in... motor racing, let's say... hardly any benefit would result for the company.

\section{Reputation and the triple-bottom-line approach}

Looked at in isolation, the triple-bottom-line approach, implemented through the agency of corporate responsibility, appears rather uneconomical. It is only when one sees the matter in a broader perspective - that is, in the context of the entire reputation phenomenon - that it becomes apparent that what at first glance seems rather strange entrepreneurial behaviour, is in fact quite rational and business focused. Swiss Re's activities on the social and environmental levels are statements on issues that the public watches as sharply as it does business. These are issues with relevance to larger questions, such as the relation of the company to society, ${ }^{12}$ the legitimacy of commerce and, ultimately, the long-term prospects for our economic system: for no corporation will be able to generate profits over the long term - sustainably - if it does not behave responsibly with respect to the social and natural environment in which it operates. In this equation, the relation between profit and responsibility is reciprocal: that is, a healthy cash flow is quite simply a necessary condition; and in the long run, responsible behaviour supports the economic bottom line.

Charity, donations, sponsoring - all corporate responsibility-related activities, actually - are forms that Swiss Re uses to legitimize its role as a responsible player, both to its stakeholders and in the forum of public opinion. It is in this way that Swiss Re gains transparency and status, and integrates itself into society in a way that it could not do through business alone. Swiss Re needs much more than capital at favourable conditions in order to create value: its key resources also include knowhow, motivated employees, social skills, innovation, negotiating leeway, acceptance, legitimacy, reputation, technology and recognition. ${ }^{13}$ Swiss $\mathrm{Re}$ is a service provider. As such, human beings - human resources - are its main raw material. Its relations with the public - its public relations - are of great importance. Why? Because its stakeholders have values and ideals that go far beyond economic considerations:

- Employees want to be proud of their company. They are more loyal to a company with a good reputation.

- Investors expect continuity and predictability in their company's communications and behaviour, because investment always means risk - and taking a risk in a company implies trust.

- Business partners want a counterparty that will treat them fairly, and that will be there when they need it - a company that will survive.

\footnotetext{
${ }^{12}$ Liebig and Morandi (2006, pp. 18-19).

13 Naumann (2003).
} 
- Lawmakers and regulatory authorities are less inclined to impose burdensome regulations when the businesses they regulate have a good reputation and are trustworthy.

- $N G O s$ evaluate companies from their very specific point of view, but they influence a broad spectrum of the public discourse and hold companies' reputation as a kind of pledge, or security (or hostage!) in order to further their agenda. ${ }^{14}$

An active commitment to values and to stakeholder-related issues increases transparency, fosters trust and reduces the pressure to introduce yet more regulations. A dynamic posture is more effective in countering volatile, complex issues in the forum of public opinion: active measures in the "corporate responsibility" context establish facts on the ground in advance, giving companies the time and insight they need to stay ahead of the game. All of this solidifies their reputation. As noted at the outset, reputation depends on communication - sometimes internal, sometimes public, but always communication.

In summary, we may state that the triple-bottom-line approach is a viable response to democratically legitimized and mass-media-formed public opinion structures and processes. The triple-bottom-line approach provides a basis and a rationale for credible and effective reputation management by combining:

- consistent entrepreneurial values (core values),

- transparent corporate governance structures and processes, and

- a sustainability-based corporate responsibility policy. ${ }^{15}$

Figure 1 shows that the elements are interrelated, and that it is only in combination that they benefit reputation management.

We will now pass to a consideration of the relevance and urgency of reputation management before turning to the question of how reputation management may be implemented.

\section{Reputation management}

\section{On the urgency and relevance of reputation management}

Why is a (good) reputation important for a profit-oriented organization? The financial services industry, to which Swiss Re belongs, regards reputation as the biggest risk to a company's market value: "When asked which types of risk represent the greatest potential threat to their company's overall market value, as opposed to earnings, more respondents cited reputational risk than any other, well ahead of the number who cited regulatory, market or credit risk."16 Quite aside from this risk aspect, reputation is

${ }^{14}$ An NGO's power in this area is derived from its ability to influence a company's social capital. Trust and reputation are constituent elements of social capital (Göbel (2002, pp. 263ff)).

${ }^{15}$ Brugger models corporate responsibility as a combination of governance, rules, sustainability principles and cultural values. (Brugger (2005, pp. 80ff)). The current model adds, by analogy, reputation.

${ }^{16}$ PricewaterhouseCoopers (2004). In another survey (The Conference Board (2006)), 658 responding CEOs and chairmen ranked corporate reputation as seventh of 91 different challenges to their business. 


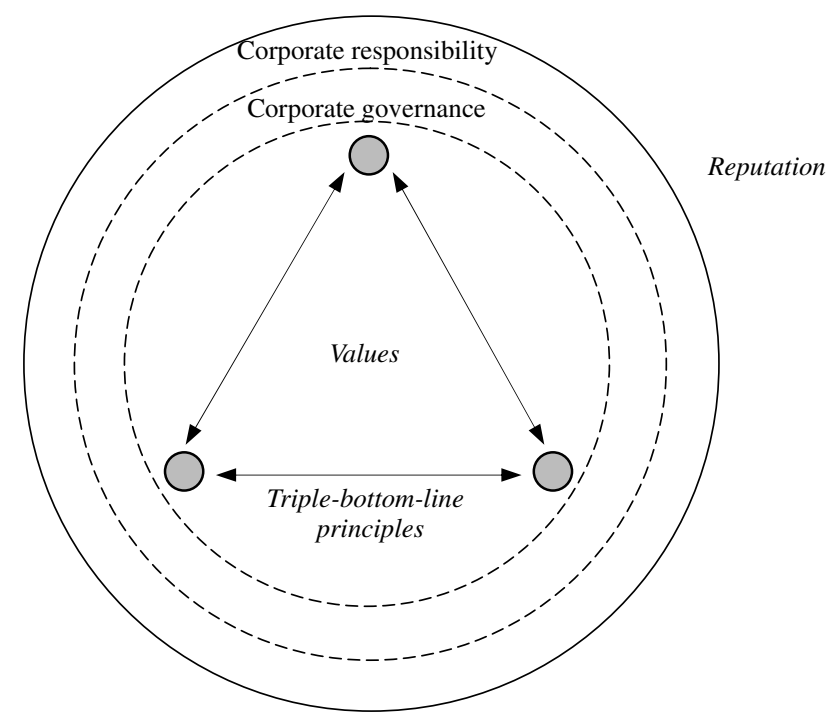

Figure 1. The basis of reputation: values, triple-bottom-line (sustainability) principles, governance structures and a responsibility policy.

also a competitive factor. ${ }^{17}$ A survey of the biggest German companies showed that reputation can positively influence performance in meeting competitive targets on many levels: ${ }^{18}$

- developing a positive image,

- heightening customer satisfaction and loyalty,

- improving customer relationships,

- enhancing corporate identity,

- acquiring new customers,

- heightening employee motivation and satisfaction,

- increasing profits and

- simplifying product launches on the market.

Yet, while the (negative) financial impacts of a lost reputation are reflected in numbers (lost assets) and are thus quantifiable, it is more difficult (though not impossible) to document and measure the positive impact - how a good reputation pays off. There is no line item for "Reputation" in any balance sheet or profit-and-loss statement. A major hurdle to calculating a convincing "value" for a good reputation is the fact that such a good reputation is usually accompanied by other positive factors such as accepted products, sound management processes, transparent reporting, etc.; hence, a

\footnotetext{
${ }^{17}$ PricewaterhouseCoopers (2004).

${ }^{18}$ Wiedmann and Buxel (2005, p. 154).
} 
ceteris paribus comparison of a company with a good reputation and one with a bad one is hardly feasible. ${ }^{19}$

Nevertheless, there have been a number of surveys and studies supporting the fact that well-reputed companies and companies with high standards of governance outperform the others:

- A recent study by Hill and Knowlton, documented in "Corporate Reputation Watch 2004", found that "there is now resounding acknowledgement from senior executives around the world that maintaining and enhancing a strong corporate reputation results in tangible business benefit, and has the power to positively influence the behaviour of a range of key stakeholders - particularly customers, investors and employees."

- An investigation carried out at the University of Basel in 2003 examined the relation between a corporation's governance and the valuation of its stock. It demonstrated a statistically significant, positive correlation between governance and valuation.

- A study by Deminor Rating in 2003 confirms for European companies that a portfolio of investments in companies with good governance outperformed a portfolio of companies that had poor governance by almost 3 per cent.

- A study by the Harvard Business School in 2002 came to the conclusion that, of a group of companies, the ones with "worst practices" produced 9.3 per cent less profit for shareholders than the ones with "best practices".

- McKinsey carried out a survey with more than 200 institutional investors in over 30 countries. According to the 2002 study, more than three-quarters of them were prepared to pay a premium of 12-30 per cent for good governance.

Let us summarize as follows: although a good reputation will go unrecorded on corporate balance sheets, it is probably the most valuable asset a company can equip itself with. Prudent reputation management - probably more than ever - has become a key success factor (or indeed, a survival factor) for a firm. ${ }^{20}$

\section{Reputation management at Swiss Re}

Apart from the reasons mentioned above, there are a number of specific factors that make it vital for a corporation to maintain its good corporate reputation. Let us show why and how this holds true for Swiss Re in particular:

First of all, Swiss Re needs highly skilled employees and to set them to work on tasks that require a large degree of independence and personal discretion. People of this calibre want to work for a company whose values they can share; they want to be

19 De la Fuente Sabate and de Quevedo Puente (2003).

${ }^{20}$ In a systematic analysis of a number of studies on the influence of corporate governance on share performance, Manz demonstrates that, seen long-term, effort in the corporate governance area produces an empirically observable, positive effect. He writes that the effect of corporate governance-related efforts on the individual investor "is quite different where the long-term investor is concerned. There, the expenditure for corporate governance mechanisms is money well spent. Over the long run, the advantages of efforts in the area of corporate governance predominate, and, ceteris paribus, the share price rises." (Manz (2005)). 
proud of the organization they work for. A good reputation is therefore critical in the competition for talent. In these respects, employees - both current and potential share the aspirations of their employer. We depend on loyal, motivated employees who can identify with the company. And since we invest a lot in our employees' education and development, Swiss Re has a keen interest in having long-term employment relationships.

Our business product - reinsurance - is invisible. We sell risk transfer, risk finance and asset management, all of which are difficult to evaluate. Consequently, the client's decision to select Swiss Re as his provider has to be and is built upon trust. You do not trust a company with a bad reputation, and you do not want to be associated with a firm that has a tainted name. Our customers want to deal with us not least because they believe in our good name, which has been built up over more than 140 years, and because they are confident they would not be running the risk of "unpleasant surprises".

This is particularly important for Swiss Re since we are in a long-term business and cannot afford an attitude that might promote short-term profits while destroying sustainable relationships and business opportunities. There may be certain business activities where you meet a client just once, but reinsurance is certainly not one of them. Reinsurance is insurance for the insurer. It is basically a "promise to pay", and the reinsurer is somehow the "risk-taker of last resort". Our clients, therefore, rely on us financially as a business partner that will - sometime in the future, perhaps as much as 20-30 years - deliver on its promise. Such a relationship must be built on trust. A good reputation not only allows us to consolidate existing business relationships, it also serves as the "door-opener" for new business opportunities.

To make our products somewhat more tangible, we rely heavily on our brand. And we are a one-brand company. Any impairment of our brand - and a loss of reputation certainly hurts a brand - will therefore hurt our business chances as a whole.

We operate globally, which means that - due to the immediate worldwide dissemination of news, particularly bad news - a tainted reputation in any part of the world will have adverse effects on our activities and financial assets worldwide.

Further, as an industry leader, Swiss Re has a fundamental interest in the untainted reputation of the insurance industry at large. As a key market player, we contribute to shaping this overall image by our own corporate behaviour, striving to be perceived as a role model by our peers, and thereby influencing their actions as well. Conversely, Swiss Re may also be hit if one (or several) of its peers suffer a reputation impairment. We are all aware of the recurring stories in the media these days on the opaque and sometimes improper business practices of the recent past in connection with contingent commissions and finite reinsurance programmes. This has negatively impacted the image of the insurance and reinsurance industry as a whole. If it persists, it may present a hazard for us by weakening our dialogue with governments, regulators and other public policymakers. Therefore, Swiss Re has a vital interest in addressing these issues and eliminating any possibly improper business practices. "No man is an island", said John Donne; no company is an island, either. We cannot fully realize our goals unless the corporate behaviour of all market participants reflects high ethical standards. 
Finally, a good reputation and standing will help to sustain the goodwill that is required in dealing with regulators, political bodies and NGOs. Companies that are treated with scepticism will have a hard time. Reputational goodwill, on the other hand, enhances good working relationships - and this is particularly important for large, global organizations, since they are often quite dependent on these constituencies, despite their own economic power:

- Regulators and other administrative bodies often have considerable discretion within their statutory competencies and are more likely to decide in favour of a wellreputed company when it comes to making the call. One example may be Swiss Re's business activities in Asia, where we started establishing a business relationship decades ago and are now in a position to expand strongly - one of our four strategic goals. With a tainted reputation, Swiss Re would certainly not have been able to attain this status and receive the necessary support of the respective regulators in emerging countries.

- Political bodies may be more willing to maintain a dialogue with well-respected companies: such dialogue is crucial since legislators have the power to change the corporate world literally with one pen-stroke, and governments have a great deal of discretion when it comes to supporting or hindering business activities.

- $N G O s$ have become more influential and need to be recognized as stakeholders. It helps to have a good reputation, to be a broadly respected entity when dealing with them.

Let us sum up briefly: stock corporations have a legal duty to their shareholders to be profitable, and they will not survive in a profit-driven environment without generating proceeds. In the long term, and for publicly owned enterprises, profitability depends in great measure on a company's reputation. Reputation building is thus a legitimate concern; indeed, it is a must for purely economic reasons.

\section{The economic value of reputation for the enterprise}

The media, in its function as "reputation watchdog", is continually juxtaposing a corporation's economic success with its environmental, social and moral values. Thus, a company's public face, its reputation, is an in-depth reflection of these issues and their interrelationships. Numerous studies prove that reputation affects a company's economic valuation. ${ }^{21}$

Enterprises with a good reputation find easier acceptance in the exchanges and capital markets, and their shares do not drop as sharply in the face of negative events. A good reputation also means easier capital access, at more favourable rates. Yet beyond the purely financial level, a good reputation also provides indirect economic benefits such as greater employee satisfaction, deeper customer loyalty and a more positive corporate image and identity. ${ }^{22}$ These direct and indirect economic benefits ultimately contribute to improving competitiveness.

\footnotetext{
${ }^{21}$ De la Fuente Sabate and de Quevedo Puente (2003).

${ }^{22}$ Wiedmann and Buxel (2005).
} 
However, economic aspects alone do not explain why companies should care about an impeccable reputation. Rather, a company's reputation must be driven by its representatives' conviction that they are doing the right thing beyond purely financial aspects - and this conviction must be shared by all employees, or at least the large majority of them. In the words of the Institute of Business Ethics: "To be ethical is profitable; but to be ethical because it is profitable is not ethical." And, one might add, it is also not profitable in the long run.

\section{Is reputation manageable?}

Yet is reputation manageable at all? If reputation is the product of public perception, is it not essentially outside a company's control? Does this not mean that reputation management is wishful thinking, or a contradiction in terms?

In reality, although management may not be able to control a company's reputation, a lot can be done to influence it. And this is where normative management instruments come in: instruments such as a corporate philosophy, corporate governance and compliance rules.

- Through its corporate philosophy, a corporation commits itself to clearly defined values.

- Through corporate governance, it develops structures to specify and implement basic values.

- Through compliance rules, it ensures that all employees adhere to these values in their day-to-day activities.

All three of these instruments positively influence stakeholder expectations; and the more stable these expectations are, the more reliable and credible the company's public image - and reputation - will become.

It is certainly important for a corporation to adhere to certain core values and formulate them in a corporate philosophy: this has been proved both in quantitative and qualitative surveys. According to a study recently undertaken by Swiss Re, 92 per cent of its employees consider our corporate philosophy to be "fairly relevant" or "very relevant" to their work; 71 per cent believe that the corporate philosophy has a positive influence on the work environment.

A survey conducted among clients and business partners confirms the importance that outsiders attach to our core values.

All of this is good news, because the preconditions for implementing such values are, first, for them to be well known, and second, for them to be considered relevant. This second precondition, particularly, can pose a problem. A corporate philosophy must be consistently applicable to every conceivable decision, process and stakeholder group in the company and also - in a global organization - to all countries in which the company is active. As a result, most corporate philosophies tend to be rather generic. They sound good in the introduction of a corporate document. They create harmony and make the reader feel comfortable, because no one could possibly be against the values usually found there: values such as integrity, excellence, efficiency or sustainability. However, unless the philosophy goes beyond the words, such 
statements are meaningless. ${ }^{23}$ Even worse, they can actually be harmful, creating a false impression of a corporation's business style. If "implementation" means just preaching adherence to some principles that are generally accepted anyway, we have not come very far.

With this, we certainly do not mean that a company should not commit itself to ethical standards and to socially responsible behaviour. What we mean is that in order to impact the daily life of an organization and its employees, the statements in the corporate philosophy must be translated into much more specific and more detailed procedures and rules of behaviour that give clear guidance where decision-making and implementation are concerned. This is where we find the interface to governance and compliance.

Governance is about structures. It deals mainly with organizational and supervisory systems, with the power sharing and with functions, with checks and balances, reporting and transparency. ${ }^{24}$ This means - among other things - transparent reporting, and a supervisory structure and auditing oversight that embraces not only financial issues but also societal and environmental ones.

Implementing core values through compliance, on the other hand, is a more transactional approach. It sets up rules on procedures and on "dos and don'ts" in performing the corporation's activities:

First, there is the group-wide organization of Swiss Re's compliance officers, coordinated by the Group Compliance Office, which monitors and supports compliance with a great number of regulations and standards, legal as well as ethical; those imposed from outside and others that Swiss Re has set for itself. For most of the 80 compliance officers, this activity is just one part of their job, and this helps compliance to penetrate all business functions. We want to sensitize our staff to ethical dilemmas, support them in dealing with these issues and empower them to act responsibly. And we want to minimize reputational risk by evaluating sensitive business cases accurately and thoroughly.

Secondly, as has become standard for public companies, Swiss Re has created a compendium of behavioural rules in a Code of Conduct. In order for it to mean more than empty words, such a code should address specific business situations: dealing, for example, with questions like the confidentiality of business information, conflicts of interest, insider trading, the thin red line between common courtesies and unacceptable gifts and payments, etc. - and all this in as concrete a fashion as possible. We distributed a booklet on our Code of Conduct to all our employees, and two excerpts may serve as illustrations.

With regard to decision-making in a situation of ethical conflict, the following advice is given:

One golden rule: ask for guidance from a trusted colleague - your Compliance Officer, supervisor, or any other employee - whenever you have doubts about the best way to proceed, prior to taking any action.

\footnotetext{
${ }^{23}$ In fact, many of the same words feature in the corporate philosophies of Swiss Re and the now almost defunct energy and communications giant, Enron.

${ }^{24}$ Volkart and Labhart (2000).
} 
These questions may also help you decide when unsure about the best way to proceed: "Are my intended actions legal and compliant with applicable legal, regulatory, and ethical standards?", “Am I being fair and honest?", "Will my actions stand the test of time?", “How will I feel about it afterwards?', “Could I justify it to my colleagues?" or "How would it look on the front page of a newspaper?"

And with regard to gifts and invitations, the booklet states:

Use your good judgement. If you have difficulty determining whether a specific gift or entertainment item lies within acceptable business practices, ask yourself: "Is it legal?", "Is it clearly business related?", "Is it moderate, reasonable, and in good taste?", "Would public disclosure embarrass Swiss Re?", "Is there any pressure to reciprocate or grant special favours?"

If still in doubt after consultation with superiors and/or the Compliance Officer, Swiss Re advises you to abstain from exchanging the gift in question.

We thus call on our employees to ask themselves questions to correctly assess any uncertainties at the conduct level. This self-assessment is a crucial step, as reputational risks often arise not through the willful disregard of rules but as a result of an employee's incorrect assessment of a situation. ${ }^{25}$ Finally, we have established a "sensitive business cases" process, making reputational risk a central theme in our business operations. Our compliance officers and specialists support our staff and act as consultants for any potentially difficult ethical issues.

At Swiss Re, we have also extended control through our Group Whistle-blowing Guidelines. Our employees are likely to be the first to know when someone inside the company or connected with the company is acting improperly or illegally and while the normal reaction should of course be to inform a superior, in extraordinary cases it may even be necessary to inform anonymously - either internally, or by turning to a person outside the firm. ${ }^{26}$

Finally, the successful implementation of compliance processes is a never-ending educational task. This means - among other things - that the Board of Directors and top management must address individual and organizational behaviour issues, and that values and roles must be actively communicated throughout the company, using all available channels - discussions and seminars in particular, as well as other means. But above all, it means that the top people must "walk the talk".

To deal with certain issues of specific importance for our organization, we use what we call the Top Topics process. ${ }^{27}$ This list of about a dozen topics of particular relevance for Swiss Re embraces some issues of internal importance, but also broader issues that are instrumental in our dialogue with the market and society. At least some of the topics - which, by the way, are changed from time to time - are relevant for our

\footnotetext{
${ }^{25}$ Leisinger (2003).

${ }^{26} \mathrm{We}$ are pleased to say, however, that the option of anonymous reporting has so far never been used.

${ }^{27}$ Schanz (2004).
} 
reputation, for example, our strategic positions with regard to climate change and watershed management.

We have also developed a Group Issue Management process, which is linked to reputation management. ${ }^{28}$ This process strengthens Swiss Re's position as a knowledge company and industry leader on certain topics of strategic relevance. These include mortality, for example, and in particular the problems of obesity and an ageing population. The topics managed within the Group Issue Management process have various value drivers:

- Some have upside potential (i.e., they may generate more business and increase revenues).

- Others attempt to provide downside protection by mitigating potential risks.

- A third category contributes to enhancing Swiss Re's brand by leveraging our expertise and is therefore relevant for our reputation.

\section{How can we measure reputation?}

There is a fairly voluminous English language literature on reputation measurement, based on a substantial number of rigorously researched and developed concepts. ${ }^{29}$ Swiss Re bases its reputation management on a number of studies and surveys, which we conduct with varying frequency. These tools help us assess our effectiveness in implementing processes for core values, corporate governance and compliance, and arriving at a reliable basis for further decision-making and action. In the field of reputation management too, we believe in the old saying that "What gets measured, gets done!'

The principal studies we use are:

- Swiss Re Reputation Survey: An external and internal measurement of Swiss Re's reputation carried out every 2-3 years. Reputation-related topics are discussed in qualitative interviews with over 300 stakeholders. The topics include: culture and image; strategy and the future; financial performance; service and relationships; communication, people and management; and corporate responsibility. ${ }^{30} \mathrm{We}$ have been carrying out these qualitative surveys since the year 2000 .

- Media evaluation: We consistently monitor published opinions in the mass media. Public opinion, as expressed by qualitative interviews with stakeholder groups, does not necessarily correspond to published opinion. However, both perspectives are relevant for our reputation.

- Brand Performance Survey: We use this survey to quantitatively gauge the perception of our values over time. Reputation and brand are interrelated. For us as a single-brand organization, the impact of our reputation on the brand is - as mentioned - particularly relevant.

\footnotetext{
${ }^{28}$ Herger (2004, pp. 294ff).

${ }^{29}$ Berens and van Riel (2004).

${ }^{30}$ Fombrun et al. (2000).
} 
- Finally, we use a cultural survey to measure aspects of corporate culture that apply to behaviour, such as belief in our core values and consistency in our approach to doing business. We use this standardized tool every $2-3$ years to produce an overall picture of what is otherwise generally assumed to be unconscious and invisible - or self-evident! We are certain that our culture contributes to a positive relationship with our stakeholders.

Swiss Re thus has a range of tools designed to shape its reputation, keep it stable or try to change it. Overall, the instruments used for measurement are configured to provide as broad a view as possible of the structure and complexity of public issues. In keeping with its triple-bottom-line approach, Swiss Re is committed to carrying this differentiated perspective over into the company's decision making and reporting. ${ }^{31}$ The stakeholders' expectations are ongoing. The more texture and detail we put into our picture of the key drivers of our company's reputation - both current and potential - the more successful we will be in reducing reputational uncertainties. We are convinced that though reputation may not be controllable, it is clearly manageable, and that, while qualitative in nature, it is to some degree measurable.

We are also convinced that we can use the instruments mentioned to heighten public confidence in Swiss Re, as well as foster internal motivation and enhance Swiss Re's reputation with all of its stakeholders.

\section{References}

Berens, G. and van Riel, C.B.M. (2004) 'Corporate associations in the academic literature: three main streams of thought in the reputation measurement literature', Corporate Reputation Review 7(2): 161-178.

Brugger, E.A. (2005) 'Die Kombination von Good Governance und Nachhaltigkeit. Verantwortungsvolle Unternehmensführung', in R. Jakob and J. Naumann (eds) Wege aus der Vertrauenskrise, Frankfurt am Main: Moderne Industrie.

Fombrun, C.J., Gardberg, N.A. and Sever, J.M. (2000) 'The reputation quotient - a multi-stakeholder measure of corporate reputation', The Journal of Brand Management 7(4): 241-255.

Forstmoser, P. (2003) 'Good Governance und Transparenz - Zwei Bausteine zum Wiederaufbau des Vertrauens in die Wirtschaft und ihre Vertreter', in R. Jakob and J. Naumann (eds) Wege aus der Vertrauenskrise, Frankfurt am Main: Moderne Industrie.

Forstmoser, P. (2005) 'Gewinnmaximierung oder soziale Verwantwortung? Zum Auftrag börsennotierter Unternehmen', in R.M. Kiesow, R. Ogorek and S. Simitis (eds) Summa - Dieter Simon zum 70 Geburtstag, Frankfurt am Main: Vittorio Klostermann.

de la Fuente Sabate, J.M. and de Quevedo Puente, E. (2003) 'Empirical analysis of the relationship between corporate reputation and financial performance - a survey of the literature', Corporate Reputation Review 6(2): 161-177.

Göbel, E. (2002) Neue Institutionenökonomik - Konzeption und betriebswirtschaftliche Anwendung, Stuttgart: UTB.

Herger, N. (2004) Organisationskommunikation. Beobachtung und Steuerung eines organisationalen Risikos, Wiesbaden: VS Verlag für Sozialwissenschaften.

Leisinger, K.M. (2003) Whistleblowing und Corporate Reputation Management, Munich: Hampp, Mering.

Liebig, B. and Morandi, P. (2006) 'Wenn die öffentliche Sache zur Firmenangelegenheit wird. Die Globalisierung gibt den Verfechtern von Umwelt und Sozialem Auftrieb', Neue Zürcher Zeitung 41: $18-19$.

\footnotetext{
${ }^{31}$ See, for example, our Annual Report.
} 
Luhmann, N. (1991) Soziologie des Risikos, Berlin: Gruyter.

Luhmann, N. (1996) Die Realität der Massenmedien, 2nd edn., Opladen: Verlag für Sozialwissenschaften.

Manz, S. (2005) Einfluss der Corporate Governance auf die Börsenperformance, Zürich: Institut für Rechnungswesen und Controlling (IRC).

Naumann, J. (2003) 'Die nicht legitimierte Rückverteilung volkswirtschaftlicher Ressourcen bremst die Dynamik des Gesamtsystems', in R. Jakob and J. Naumann (eds) Wege aus der Vertrauenskrise, Frankfurt am Main: Moderne Industrie, pp. 19-62.

Neue Zurcher Zeitung (2006) No 18.13, 23 January.

PricewaterhouseCoopers (np 2004) Uncertainty tamed? The evolution of risk management in the financial services industry, A joint project with The Economist Intelligence Unit.

Ripperger, T. (1998) Ökonomik des Vertrauens - Analyse eines Organisationsprinzips, Tübingen: Mohr Siebeck.

Schanz, K.-U. (2004) 'Issue management in (re)insurance: an emerging strategic challenge', The Geneva Papers on Risk and Insurance - Issues and Practice 29(2): 334-341.

The Conference Board (2006) CEO Challenge 2006, New York.

Ulrich, P. and Fluri, E. (1995) Management - Eine konzentrierte Einführung, 7th edn., Stuttgart: UTB.

Volkart, R. and Labhart, P. (2000) 'Investor Relations als Wertsteigerungsmanagement', in K.R. Kirchhoff and M. Piwinger (eds) Die Praxis der Investor Relations - Effiziente Kommunikation zwischen Unternehmen und Kapitalmarkt, Neuwied: Luchterhand Fachb, pp. 146-161.

Wiedmann, K.-P. and Buxel, H. (2005) 'Corporate reputation management in Germany. Results of an empirical study', Corporate Reputation Review 8(2): 145-163.

\section{About the Authors \\ Peter Forstmoser is Chairman of the Board of Directors, Swiss Re. Nikodemus Herger is Head of Corporate Branding, Swiss Re.}

